\title{
RISING WATER FLOW AS A FACTOR OF ORGANIC MATERIAL IMPORTATION INTO CAVES
}

\author{
NARAŠČANJE NIVOJA VODE KOT FAKTOR VNOSA \\ ORGANSKEGA MATERIALA V JAME
}

\author{
Isabel Pires Mascarenhas Ribeiro de OLIVEIRA ${ }^{1, \star}$, Daniel CORREA ${ }^{2}$, \\ Rodrigo Lopes FERREIRA ${ }^{3} \&$ Augusto Sarreiro AULER ${ }^{4}$
}

\begin{abstract}
UDC 551.444.3:551.3.051(815.142.5)

Isabel Pires Mascarenhas Ribeiro De Oliveira, Daniel Correa, Rodrigo Lopes Ferreira \& Augusto Sarreiro Auler: Rising water flow as a factor of organic material importation into caves The Carlúcio Cave is located on the left bank of the Peruaçu River canyon, in a National Park located in the semiarid zone of Minas Gerais, Southeastern Brazil. Although the Carlúcio Cave is in an unfavorable relief position in terms of material importation into its interior, it harbors an important fossil deposit. This paper sought to investigate such fossil assemblage and describe material importation and deposition events. For that purpose, a survey of the existing fossils was conducted, including a description of the deposition sites and taphonomic signatures. A topographic survey was carried out of representative samples and the deposit chronology was established by means of carbon-14 and uranium-series dating. The fossil assemblage comprises mainly terrestrial epigeal mollusk shells, totaling 1,399 individuals, $70 \%$ of which are Drymaeus sp. (Bulimuloidea, Bulimulidae). In addition, 20 bones, 57 vegetal deposition sites, four charcoals, one palm fruit and one corncob were recorded. The cave location and morphology and the deposit's taphonomic signature indicate that the material was carried upward by the rise in water level (WL) of the Peruaçu River due to episodic barriers to the natural river flow, followed by floating and retention of the material once the WL went gradually down. At least four flood events that reached the Carlúcio Cave were identified in the Peruaçu River canyon during the Holocene. This study provides evidence of a mechanism of material transport and accumulation in the cave caused by the rising water flow in connection with flood events in the river canyon.
\end{abstract}

Key words: Cave deposits, Holocene chronology, fluvial geomorphology, Peruaçu River canyon.
Izvleček

UDK 551.444.3:551.3.051(815.142.5)

Isabel Pires Mascarenhas Ribeiro De Oliveira, Daniel Correa, Rodrigo Lopes Ferreira \& Augusto Sarreiro Auler: Naraščanje nivoja vode kot faktor vnosa organskega materiala v jame

Jama Carlúcio je na levem bregu kanjona reke Peruaçu v nacionalnem parku na polpuščavskem območju province Minas Gerais v jugovzhodni Braziliji. Čeprav je jama v neugodnem reliefnem položaju glede vnosa materiala, v njej ležijo pomembne fosilne najdbe. Ta članek je poskušal raziskati fosile in opisati dogodke vnosa in odlaganja materiala. Zato smo pregledali obstoječe fosile ter med drugim opisali odlagališča in tafonomske podpise. Izvedli smo topografsko raziskavo reprezentativnih vzorcev ter $\mathrm{z}$ določanjem starosti z ogljikom C14 in uranovo serijo vzpostavili depozitno kronologijo. Fosilni ostanki obsegajo predvsem kopenske epigealne mehkužce s 1399 posamezniki, od tega 70 \% Drymaeus sp. (Bulimuloidea, Bulimulidae). Poleg tega smo opazili 20 kosti, 57 rastlinskih tališč, štiri oglja, eno palmovo sadje in eno koruzo. Lokacija jame, njena morfologija in tafonomske raziskave sedimentov nakazujejo, da je material odneslo navzgor s porastom nivoja vode reke Peruaçu zaradi epizodnih ovir pri naravnem toku reke. Temu sledi lebdenje in zadrževanje snovi, ko je nivo postopoma upadel. V holocenu smo v kanjonu reke Peruaçu identificirali vsaj štiri poplavne dogodke, ki so segli v jamo Carlúcio. Ta študija dokazuje mehanizem materialnega transporta in akumulacije $\mathrm{v}$ jami, ki jo povzroča naraščajoči nivo vode $\mathrm{v}$ povezavi s poplavnimi dogodki v rečnem kanjonu.

Ključne besede: jamski sedimenti, holocenska kronologija, rečna geomorfologija, kanjon reke Peruçu.

\footnotetext{
${ }^{1}$ Center of Studies on Subterranean Biology, Department of Biology, Federal University of Lavras, MG, Brazil. e-mail: imascarenhasoliveira@gmail.com

${ }^{2}$ Observatório Espeleológico, Belo Horizonte, MG- Brazil. e-mail: dangeobr@yahoo.com.br

${ }^{3}$ Center of Studies on Subterranean Biology, Department of Biology, Federal University of Lavras, MG, Brazil. e-mail: drops@dbi. ufla.br

${ }^{4}$ Instituto do Carste, Belo Horizonte, MG - Brazil. e-mail: aauler@gmail.com

* Corresponding author.
}

Received/Prejeto: 09.05.2017 


\section{INTRODUCTION}

Cave deposit studies have singularly contributed to the understanding of paleoenvironments. Chemical deposits have proved to be excellent paleoclimatic markers of the Pleistocene, while clastic deposits have helped understand the dynamics of caves and their surroundings. Recent studies on organic deposits in caves have brought promising results as to their geochronological application and paleoenvironmental significance (e.g., Neves \& Piló 2003; Auler et al. 2006; 2009; White 2007; Polk et al. 2007; Wang et al. 2007; Moldovan et al. 2011; Hubbe et al. 2011; Hubbe \& Auler 2012).

Caves in which identification of organic deposits is most probable are those whose relief position facilitates material importation (e.g., caves in doline bottoms and caves linked to fluvial drainage). Literature provides extensive descriptions of organic deposits in caves, and such occurrences are usually temporally correlated to clastic import events.

Organic deposits in the Carlúcio Cave consist of a remarkable fossil assemblage, particularly shells. This kind of deposit is commonly found in Brazilian caves, but few studies address their paleoenvironmental significance (e.g., Cartelle et al. 1998; Ferreira 2003; Baptista \& Morato 2003). This study analyzes organic deposits found in the Carlúcio Cave from a geomorphological perspective, i.e., it takes into consideration the cave position and the source areas of organic material. This approach involves clear paleoenvironmental significance, since the present conditions could not lead to the formation of such deposits.

This paper seeks to correlate events of organic material import and deposition in the Carlúcio Cave with specific former environmental conditions that led to the formation of these deposits. The content of such deposits was used as proxy chronological records for the recent paleoenvironmental reconstruction of the Peruaçu valley. This paper also presents the inventory, taphonomy, chronology, and paleoenvironmental assessment of the Carlúcio Cave fossil assemblage. The results can also be taken as additional input to better understand the region's prehistoric human occupation: once it was found charcoal a corncob on the fossil assemblage.

\section{STUDY AREA}

\section{THE KARST OF THE PERUAÇUY RIVER AND CARLÚCIO CAVE}

The Carlúcio cave is located on the left bank of the Peruaçu River canyon, in a National Park in the semi-arid region of Minas Gerais state, southeastern Brazil. It is one of the most important, internationally relevant speleological and geomorphological sites (Piló \& Rubbioli 2003).

The Peruaçu River bed is a fluvio-karstic system consisting of an approximately 17-km-long breakdown canyon with surface and underground (cave) reaches, marked by a sequence of sinks and resurgences (Fig. 1). The canyon develops into Neoproterozoic carbonate sequences of the Bambuí Group, with sub-horizontal limestone with 90\% $\mathrm{CaCO}_{3}$ content (Piló \& Rubbioli 2003).

The Carlúcio Cave is located on the left bank of the Peruaçu River canyon on medium to steep slope (Fig. 2. Entrance coordinates UTM 579.224 and 8.332.151; axis 23L; Córrego Alegre Datum). The cave is located upstream of the Brejal Cave, which is the first underground section along the Peruaçu River (Fig. 1).

The Carlúcio Cave has a single entrance approximately 22 meters above the Peruaçu River bed. This entrance is the highest point; the cave floor is three to nine meters below this elevation. The cave features a straight planimetric pattern in a single 160-m long conduit (horizontal projection) split into two different compartments. The first compartment is about 100-m long over a descending plane starting at the entrance. It is wide, photic, and covered with clastic deposits. The second compartment is almost perpendicular to the first one and shows a number of rimstone dams in the twilight zone at the immediate transition with the first compartment. This conduit becomes narrow, low and totally aphotic as it advances toward the cave interior. The cave floor, walls, and ceiling are covered with chemical sediments. The second compartment's morphology is marked by the presence of rimstone dams and columns that set many individual chambers apart (Fig. 2).

This paper's study area is the aphotic compartment of the Carlúcio Cave. This compartment shelters the largest fossil deposit and shows minimal external disturbance. Fossils are found in all environments of the aphotic area in association with chemical deposits and cave floor and walls. In the photic area of the cave, few organic deposits are also found, but this portion of the cave was not considered for the research since it shows large external influence that could compromise the data source. 


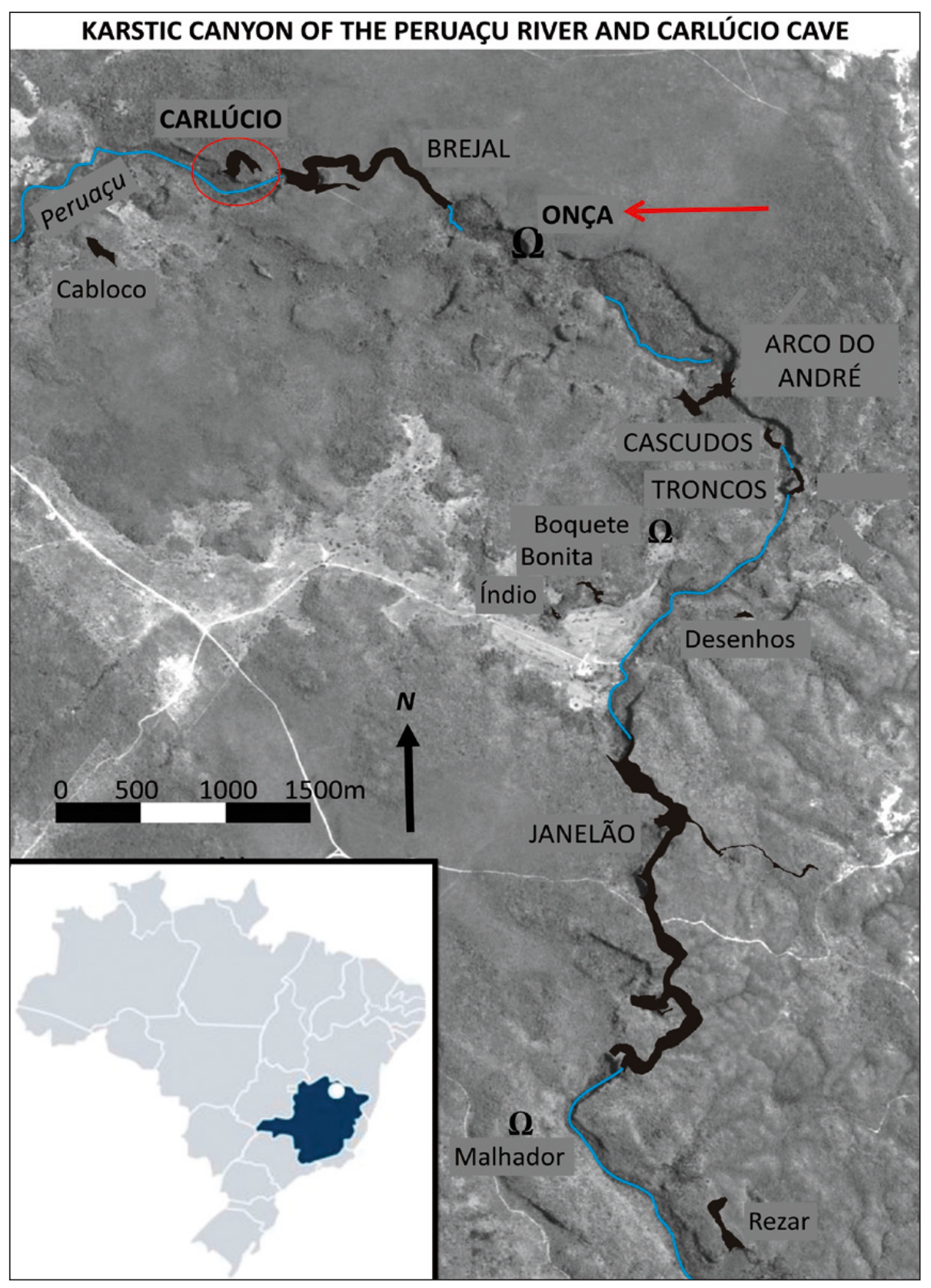

Fig. 1: Location of the karstic canyon of Peruaçu River, highlighting the Carlúcio Cave area. The arrow indicates the location of the Onça Cave, where the Peruaçu River is siphoned due to presence of a large breakdown block deposit. Source: Rubbioli et al. (2003).

\section{PERUAÇU RIVER FLOODS}

The opening of the Peruaçu River canyon by collapse and exposure of the drainage gave rise to large deposits of breakdown blocks. These are huge clastic deposits that cover the ground and sometimes obstruct the river flow.

The occurrence of large floods in the Peruaçu River has already been reported by several authors who describe the river siphoning by breakdown block deposits as the cause of such floods (Anjos 1918; Rubbioli 1999; Ferreira et al. 2003; Oliveira 2008; Oliveira et al. 2009; Coelho 2013; Rodet et al. 2015).

Upon studying logs found in the Carlúcio Cave photic zone, Coelho (2013) maintains that it is possible to associate log importation to the existence of a large deposit of breakdown blocks in the Onça Cave a few kilometers downstream (Fig 1). According to Coelho, the resulting siphoning at this point could have raised the water level (WL) by up to six meters above the Carlúcio Cave entrance elevation. It is believed that the WL rise up to this elevation is due to both natural flow limitation and periods of greater water availability. The author's findings point to tree log ages of $340 \pm 20$ years BP (Tr-01) and $800 \pm 20$ years BP (Tr-02) (Tab. 1). 


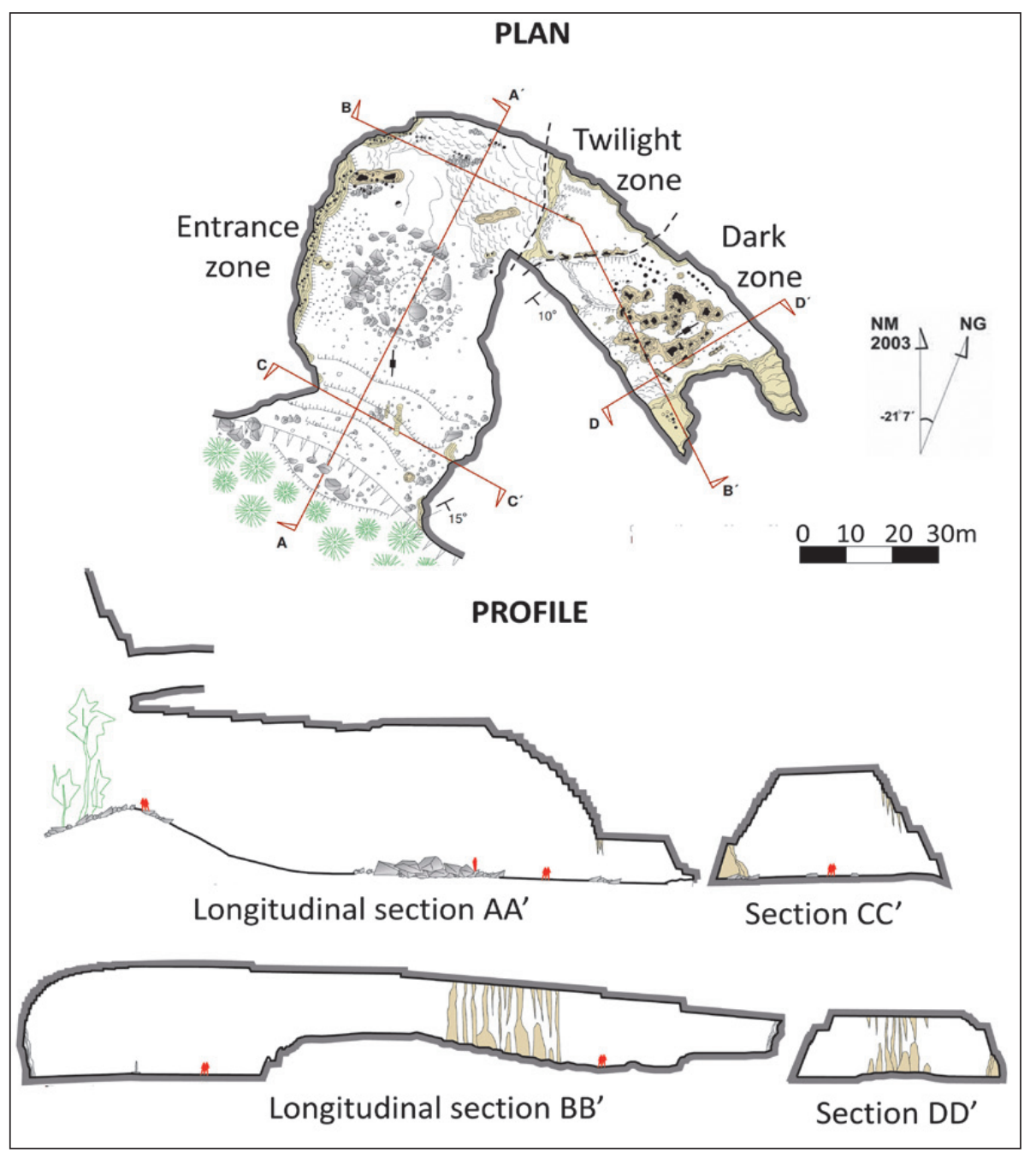

Fig. 2: Topographic plan and sections of Carlúcio Cave. Source: Modified from GBPE (2003).

Tab. 1: ${ }^{14}$ C dating of tree logs found in the Carlúcio Cave by Coelho (2013).

\begin{tabular}{|l|c|c|c|c|c|}
\hline Sample ID & Lab number & Material dated & $\begin{array}{c}{ }^{13} \mathrm{C} /{ }^{12} \mathrm{C} \\
\text { Ratio }\end{array}$ & $\begin{array}{c}\text { Conventional age } \\
\text { ( }{ }^{14} \text { C age yr, BP) }\end{array}$ & pMC \\
\hline Tr-01 (TC-05)* & UGAMS - 12595 & wood & -27.1 o/oo & $340 \pm 20$ & $95.82 \pm 0.26$ \\
\hline Tr-02 (TC-04)* & UGAMS - 12594 & wood & -25.5 o/oo & $800 \pm 20$ & $90.53 \pm 0.25$ \\
\hline
\end{tabular}

\section{METHODS AND TECHNIQUES}

A comprehensive fossil survey was carried out, including a description of the deposition site and taphonomic signatures. The base map used to locate the identified fossils is BCRA grade 4C, which was kindly provided by a speleology group (GBPE 2003). The height of the fossils in relation to the Peruaçu River bed was determined by means of field topographic survey. Data were digitalized through OnStation and CorelDraw software.

Shells of the Drymaeus and Megalobulimus genera were identified to the lowest taxonomic level accord- ing to Simone (2006), since they are the most abundant shells. The remaining shells were grouped in the Pulmonata category. A corncob was found and identified in comparison to material described by Freitas (2001). Bones of large mammals were identified to species level, whereas in the case of the palm fruit, the identification was limited to the family. The remaining plant remains and bones were not taxonomically identified given the degree of material alteration.

The deposition chronology was determined by car- 
bon-14 dating of organic remains conducted by Beta Analytic (Florida, USA) and through uranium-series dating of the respective calcite covers carried out at the University of Minnesota (USA). The age found by ${ }^{14} \mathrm{C}$ dating represents the maximum age, whereas the calcite cover age was the minimum age of imports.

Three samples were dated by means of ${ }^{14} \mathrm{C}$, one tree log and two shells of Megalobulimus sp. located at high elevations and at distant deposition sites. Shell samples F-02 and F-06 were submitted to etching pre-treatment and the log sample F-03 to an acid / alkaline / acid sequence treatment. Radiometric analysis was applied to samples F-02 and F-03, and atomic mass spectroscopy (AMS) method was used for sample F-06. Calibrations were calculated based on Reimer et al. (2004) and Talma and Vogel (1993) using the IntCal04 database.

${ }^{230} \mathrm{Th} /{ }^{234} \mathrm{U}$ uranium-series dating was carried out through the inductively coupled plasma mass spectrometry (ICP-MS) method. The respective half-lives were established according to Cheng et al. (2000). The samples, notably F-02, presented detritic contamination, which was corrected for initial ${ }^{230 \mathrm{Th}}$ using an initial ${ }^{230} \mathrm{Th} /{ }^{232} \mathrm{Th}$ atomic ration of $4.4 \times 10^{-6} \pm 2.2 \times 10^{-6}$. Those are the values for a material at secular equilibrium, with the crustal ${ }^{232} \mathrm{Th} /{ }^{238} \mathrm{U}$ value of 3.8. Errors are arbitrarily assumed to be $50 \%$.

\section{IMPORT OF MATERIALS, ESPECIALLY SHELLS, INTO CAVES}

Lund (1845) recognizes five processes through which materials are carried into caves: (1) carried by predators;
(2) fall into cracks; (3) death of animals while crossing a cave; (4) death of resident animals; and (5) transport by runoff. The latter stands out as the prevailing material importation mechanism, which is already well established in Brazil (e.g., Lund 1845; Paula Couto 1953; Cartelle 1994; Souza 1999; Auler et al. 2009).

Chambers and Steadman (1986) define the following means of importing epigeal terrestrial mollusks - the prevailing organisms in the Carlúcio Cave's fossil assemblage - into caves: (1) retreated into moist areas during daily or the dry season; (2) carried by birds, rodents, or lizards as prey items; or (3) transported along with the sediment influx during periods of extremely high rainfall. Importation through sediment flow is pointed out by the authors as the prevailing form of accumulation of terrestrial mollusks in caves.

Inventories and taphonomic and paleoenvironmental studies of molluscan fossil assemblages are commonly found in the literature, but they refer mainly to sedimentary deposits and notably occurrences of aquatic species (e.g., Clifton 1971; Cowling et al. 1999; Walker \& Goldstein 1999; Aguirre \& Farinati 1999; Kidwell 2001; Yesares-García \& Aguirre 2004; Yanes et al. 2008; Szymanek et al. 2016). The few studies on the occurrence of epigeal terrestrial mollusk deposits in caves confirm that they are associated with sediment deposits (e.g., Ložek 1980; Chambers \& Steadman 1986; S. Alexandrowicz 2000; W. Alexandrowicz 2000; Svoboda et al. 2000; W. Alexandrowicz \& Stworzewicz 2003; W. Alexandrowicz \& Rudzka 2006).

\section{RESULTS}

\section{FOSSILS SURVEY}

The fossil assemblage found in the Carlúcio Cave's aphotic zone comprises mainly shells of epigeal terrestrial mollusks of the families Bulimulidae and Megalobulimidae. No extinct taxa have been identified, and the species identified still occur in the study area. Tab. 2 shows the survey results, and Figs. 3-5 illustrate some of our findings.

\section{DEPOSIT TAPHONOMY}

The Carlúcio Cave fossils are not associated with sediment deposits. These fossils are abundantly distributed across different cave elevations and plan. The greatest fossil concentration and diversity are found in the innermost portions of the cave, associated with calcite floors and great diversity of speleothems (Fig. 6).
Bones are associated with calcite floors or rimstone dams, showing greater weight and pointing to possible transport near the cave floor. Vegetal material was found associated with varied chemical deposits, almost all cemented with calcite. With specific regard to shells, 1001 records were cemented with calcite or embedded in speleothems or gaps, while 398 were loosened.

Most of the fossils are found along columns or close to such speleothems' base. The incrustation type is related to the type of speleothem with which the material is associated. Most of the encrusted samples have smooth surfaces as a result of the seepage water flow over the fossils in rimstones, columns, stalagmites and flowstones. Fossils found inside rimstone dams show a rough surface, with a high level of incrustation as a result of their partial or total immersion in water (Figs. 7, 8). 
Tab. 2: Census and taxonomy of fossils found in the Carlúcio Cave.

\begin{tabular}{|l|l|l|}
\hline TYPE & QUANTITY (un) & REMARKS \\
\hline $\begin{array}{l}\text { Terrestrial } \\
\text { mollusk shells }\end{array}$ & 1,399 & $\begin{array}{l}\text { 990 Drymaeus sp. Albers, 1850 (Bulimuloidea: } \\
\text { Bulimulidae); } \\
\text { 171 Megalobulimus sp. Miller, 1878 } \\
\text { (Strophocheiloidea: Megalobulimidae); } \\
238 \text { order Pulmonata. }\end{array}$ \\
\hline Bones & 20 & $\begin{array}{l}16 \text { bones of small animals } \\
01 \text { skeleton of Passeriform; } \\
03 \text { bones of large mammals. }\end{array}$ \\
\hline $\begin{array}{l}\text { Vegetal } \\
\text { deposition site }\end{array}$ & 57 & Leaves, logs and branches. \\
\hline $\begin{array}{l}\text { Deposition } \\
\text { level of vegetal } \\
\text { remains }\end{array}$ & 01 & $\begin{array}{l}\text { Record around a column was identified as WL Mark in } \\
\text { a lentic environment. }\end{array}$ \\
\hline Charcoal & 04 & Carbonized vegetal material. \\
\hline Palm fruit & 01 & Family Arecaceae Jussieu, 1789. \\
\hline Corncob & 01 & Zea mays mays Linnaeus, 1753. \\
\hline
\end{tabular}

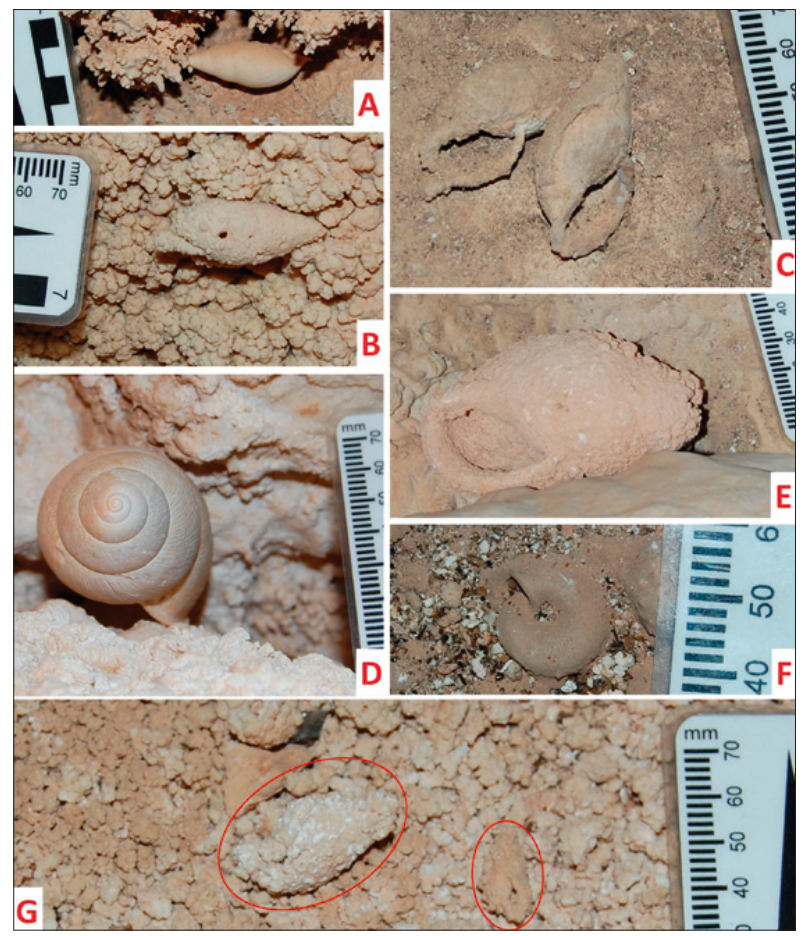

Fig. 3: A) B) and C) encrusted Drymaeus sp. Shells; D) and E) Megalobulimus sp. shells; F) shell of the subfamily Streptaxinae, generically belonging to the order Pulmonata; $G$ ) very encrusted shells, generically belonging to the order Pulmonata. Source: Oliveira (2008).
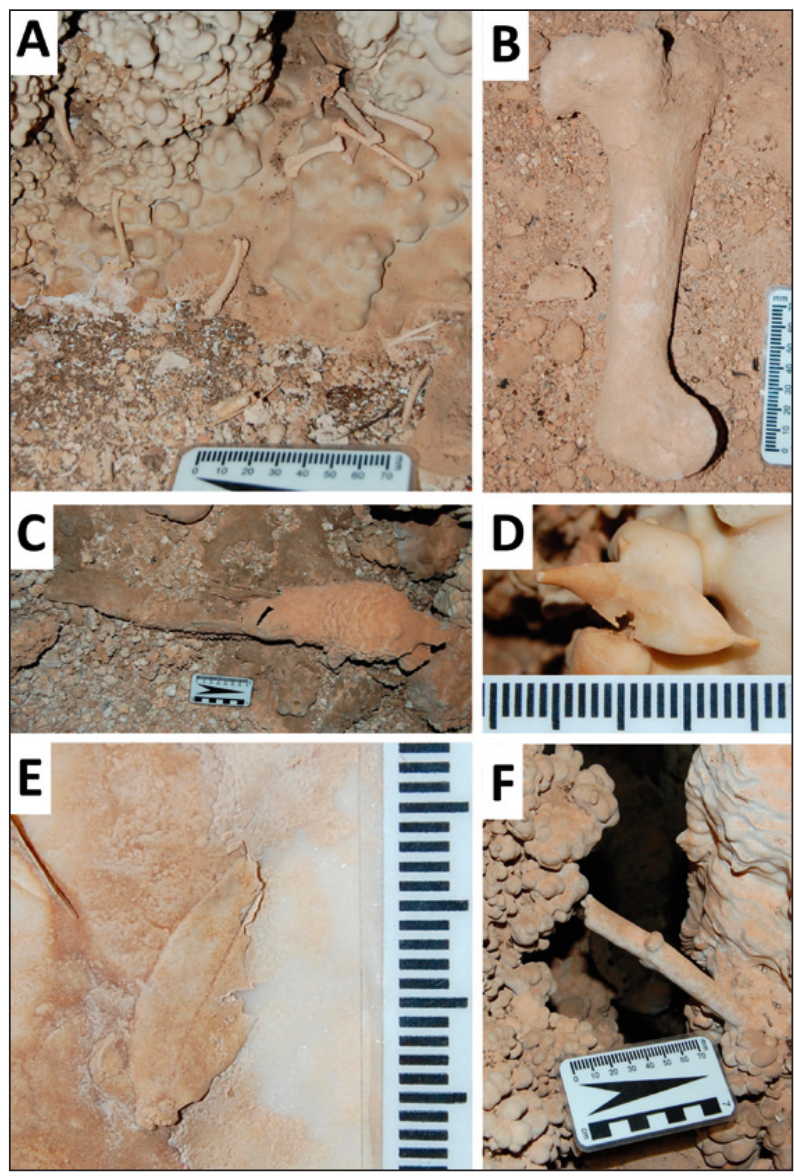

Fig. 4: A) disarticulated Passeriform skeleton; B) humerus of Tapirus terrestris (tapir); C) and F) incrusted tree logs; D and E) fossilized leaves found in column speleothems. Source: Oliveira (2008). 
Leaves, logs and branches are dispersed on the floor (Fig. 4 C) usually close to speleothems' base, and found at a height, deposited above floor level indicating flotation (Fig. 4 D, E, F).

Shell fossils were intact and had no sediments in their inner cavities. Shells in the aphotic zone of caves experience little or no predation or bioerosion.

Shell apex shows a planar, polymodal orientation, without flow orientation (Kidwell et al. 1986). There is no preferred orientation of the concavity in the vertical direction. The upward position of concavity in many samples indicates a decantation mechanism, but corresponds to a hydrodynamically unstable position easily reworked by post-deposition perturbations, such as emptying of the cave or subsequent floods.

The main fossil locations were recorded in relation to the Peruaçu River bed (Fig. 9). A Drymaeus sp. shell was the highest record, $19.6 \mathrm{~m}$ above river level. Dated samples were at $14.4 \mathrm{~m}$ (F-02 Megalobulimus sp.), $19.1 \mathrm{~m}$ (F-03 tree log), and $19.3 \mathrm{~m}$ (F-06 Megalobulimus sp.) above the Peruaçu River water level (Tab. 5). A WL mark was found in a lentic environment surrounding a column in the distal portion of the second cave compartment, at $16.9 \mathrm{~m}$ above the river bed. Also, a leaf was recorded at $19.1 \mathrm{~m}$ above the Peruaçu River water level.

\section{CHRONOLOGY}

Dating flood events that led to fossil importation is possible only indirectly. Carbon-14 dated ages refer to fossil material at the time the organism died and became
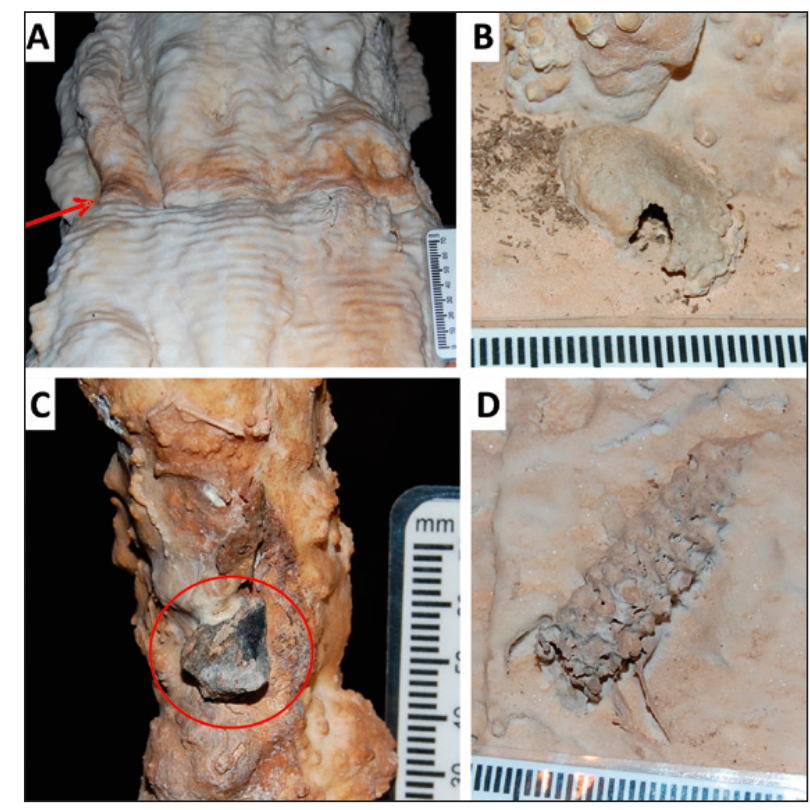

Fig. 5: A) Water level mark in a lentic environment containing vegetal remains around a column speleothem; $B$ ) encrusted palm fruit of the family Arecaceae; C) charcoal in a column speleothem; and D) fossilized Zea mays mays corncob. Source: Oliveira (2008).

available in the environment, which possibly took place some time before the transport and deposition event. Conversely, the ages of ${ }^{230} \mathrm{Th} /{ }^{234} \mathrm{U}$-dated samples represent both the age of the samples' calcite cover and the minimum age of the events, as the calcite layer deposition was subsequent to the material importation (Tab. 3; Tab. 4; Tab. 5).

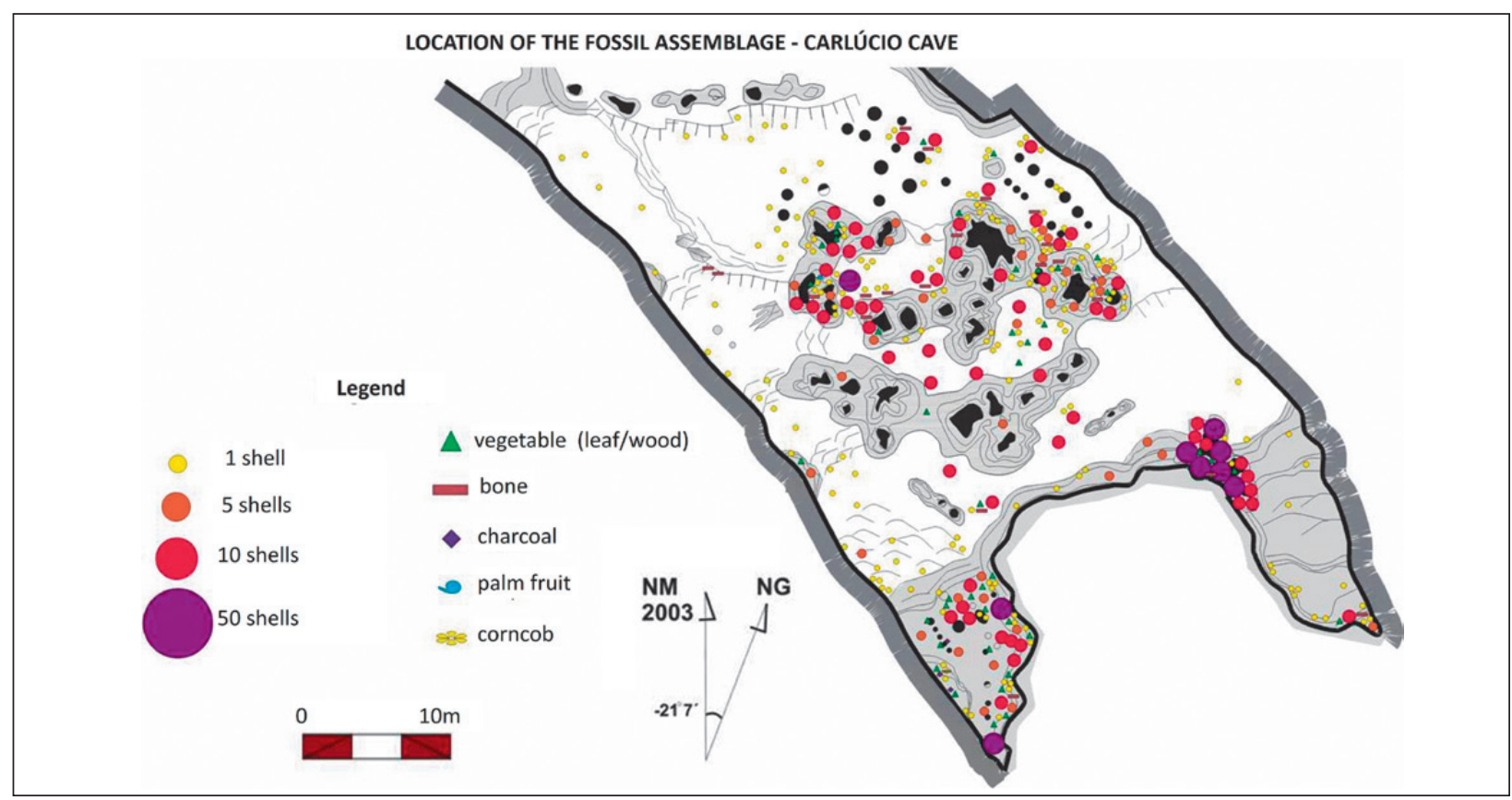

Fig. 6: Location of the fossil assemblage in the Carlúcio Cave's aphotic zone. Source: Oliveira (2008). 
Tab. 3: Age of 14C-dated fossil samples.

\begin{tabular}{|c|c|c|c|c|c|}
\hline Sample ID & Lab number & Material dated & $\begin{array}{l}13 \mathrm{C} / 12 \mathrm{C} \\
\text { Ratio }\end{array}$ & $\begin{array}{l}\text { Conventional age } \\
\text { (14C yr BP) }\end{array}$ & $\begin{array}{l}2 \sigma \text { Calibration } \\
\text { (Cal yr BP) }\end{array}$ \\
\hline $\mathrm{F}-02$ & Beta - 240538 & shell & $-11.7 \%$ o & $3260 \pm 50$ & $3600-3380$ \\
\hline F-03 & Beta - 240539 & wood & $-26.4 \% o$ & $1610 \pm 50$ & $1610-1390$ \\
\hline $\mathrm{F}-06$ & Beta - 240540 & shell & $-8.4 \% \circ$ & $9650 \pm 40$ & $\begin{array}{l}11190-11060 \text { and } 11020-11010 \text { and } 10960- \\
10800\end{array}$ \\
\hline
\end{tabular}

Tab. 4: Uranium-Thorium-dated calcite covers.

\begin{tabular}{|l|c|c|c|c|c|c|c|c|}
\hline $\begin{array}{l}\text { Sample } \\
\text { ID }\end{array}$ & 238U (ppb) & $\begin{array}{c}\text { 232Th } \\
\text { (ppt) }\end{array}$ & $\begin{array}{c}\text { d234U } \\
\text { measured }\end{array}$ & $\begin{array}{c}\text { [230Th/238U] } \\
\text { activity }\end{array}$ & $\begin{array}{c}\text { [230Th/232Th] } \\
\text { (ppm) }\end{array}$ & $\begin{array}{c}\text { Age } \\
\text { uncorrected }\end{array}$ & $\begin{array}{c}\text { Age } \\
\text { corrected }\end{array}$ & $\begin{array}{l}\text { d234Uinitial } \\
\text { d234t }\end{array}$ \\
\hline F-02 & $335.2 \pm 1.0$ & $12494 \pm 48$ & $299.7 \pm 4.5$ & $0.03062 \pm 0.00111$ & $13.5 \pm 0.5$ & $2.594 .9 \pm 95.7$ & $1.758 .5 \pm 430.5$ & $301.2 \pm 4.5$ \\
\hline F-06 & $1230.0 \pm 3.2$ & $2362 \pm 7$ & $371.4 \pm 1.9$ & $0.09914 \pm 0.00051$ & $850.5 \pm 4.5$ & $8.149 .0 \pm 44.7$ & $8.108 .5 \pm 49.0$ & $380.0 \pm 2.0$ \\
\hline
\end{tabular}

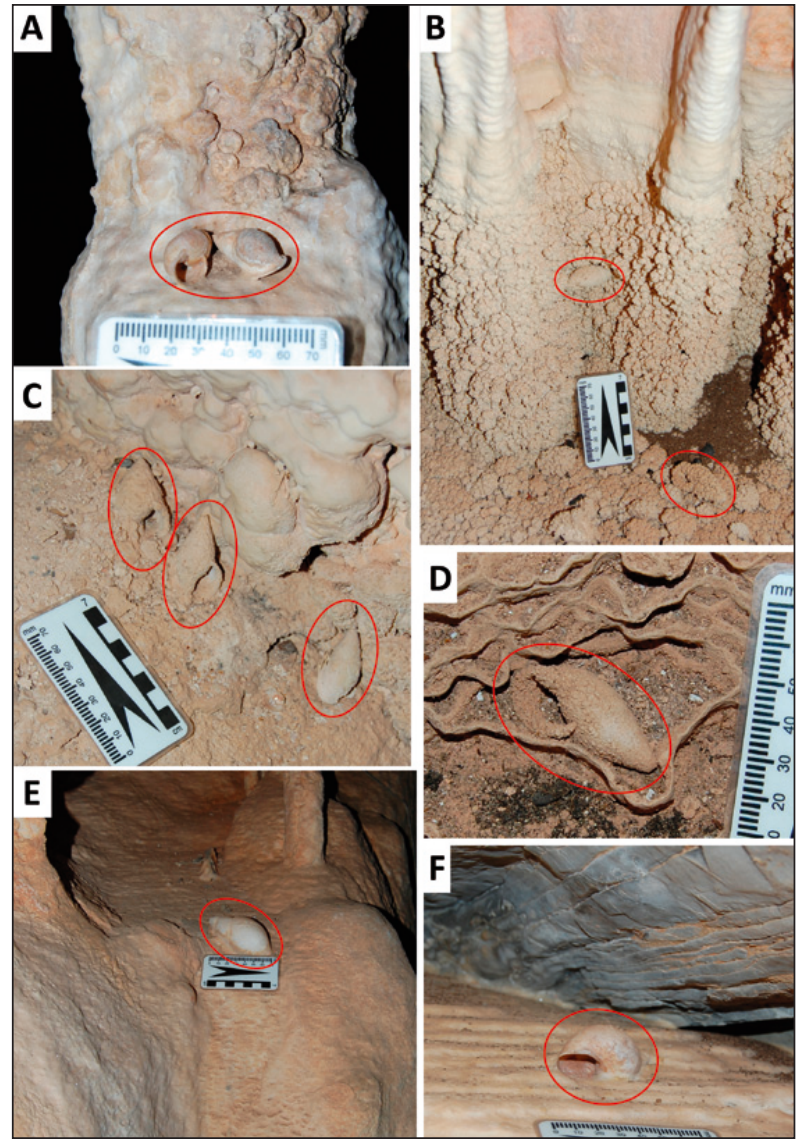

Fig. 7: A) and B) shells found in columns and column bases; C) in calcitic floor; D) in rimstone dam; E) and F) flowstone. Source: Oliveira (2008).

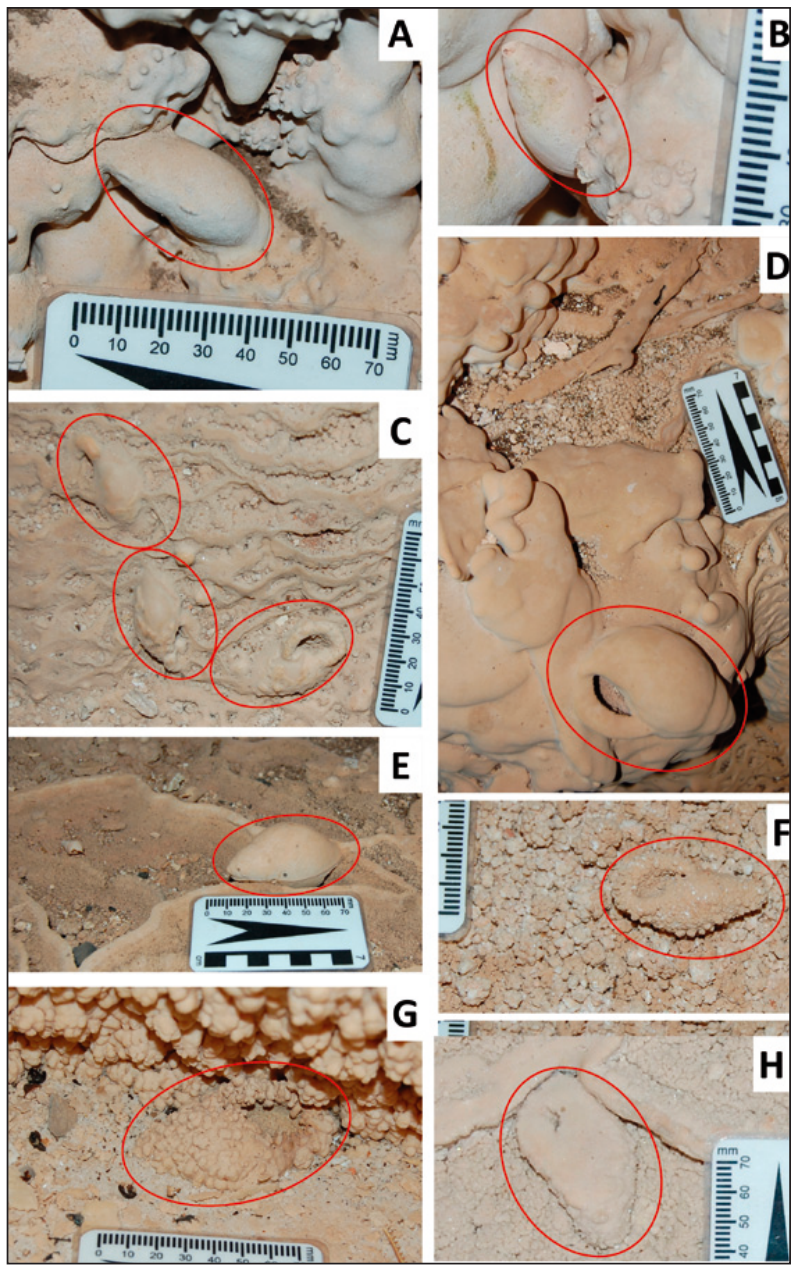

Fig. 8: Smooth surface incrustations associated to A) and B) columns, C) rimstone micro-dams, D) flowstone, and E) rimstone dam edges. Rough surface incrustations associated to F) and G) rimstone dams. Mixed surface incrustation at $H$ ) with smooth upper face and rough lower face at the rimstone dam edge. Source: Oliveira (2008). 
Tab. 5: Altimetric and chronological data of dated samples.

\begin{tabular}{|c|c|c|c|c|}
\hline Sample ID & $\begin{array}{l}\text { Material dated / Lab. } \\
\text { number }\end{array}$ & Age (yr BP) & Correlation & $\begin{array}{c}\text { Altimetry } \\
\text { (above the Peruaçu River bed level } \\
\text { during the dry season) }\end{array}$ \\
\hline \multirow{2}{*}{$\mathrm{F}-02$} & $\begin{array}{c}{ }^{14} \mathrm{C} \text { in shell } \\
\text { Beta - } 240538\end{array}$ & $3260 \pm 50$ & Maximum age ${ }^{1}$ & \multirow{2}{*}{$14.4 \mathrm{~m}$} \\
\hline & Calcite cover ${ }^{230} \mathrm{Th} /{ }^{234} \mathrm{U}$ & $1701.5 \pm 430.5$ & Minimum age ${ }^{2}$ & \\
\hline F-03 & $\begin{array}{c}{ }^{14} \mathrm{C} \text { in wood } \\
\text { Beta - } 240539\end{array}$ & $1610 \pm 50$ & Maximum age ${ }^{1}$ & $19.1 \mathrm{~m}$ \\
\hline \multirow{2}{*}{ F-06 } & $\begin{array}{l}\text { AMS }{ }^{14} \mathrm{C} \text { in shell } \\
\text { Beta }-240540\end{array}$ & $9650 \pm 40$ & Maximum age ${ }^{1}$ & \multirow{2}{*}{$19.3 \mathrm{~m}$} \\
\hline & Calcite cover ${ }^{230} \mathrm{Th} /{ }^{234} \mathrm{U}$ & $8051.5 \pm 49.0$ & Minimum age ${ }^{2}$ & \\
\hline
\end{tabular}

${ }^{1}$ Direct determination on fossil;

${ }^{2}$ Dating of overlying material

\section{LEVEL OF DEPOSITION OF THE SAMPLES \\ DATED, HIGHER SAMPLE DEPOSITED AND \\ WATER MARK LEVEL IN THE PROFILE OF CARLÚCIO CAVE}

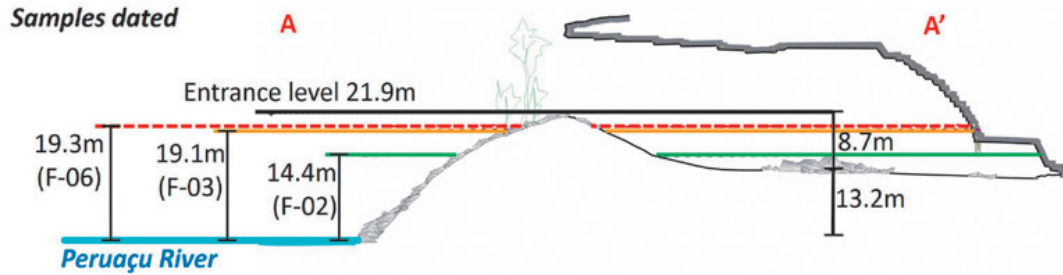

Peruaçu River

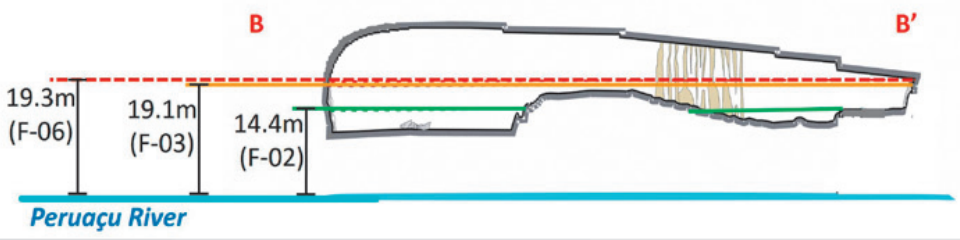

Higher sample and water mark level

A

Entrance level $21.9 \mathrm{~m}$

Maximum level $19.6 \mathrm{~m}$ Water mark level $16.9 \mathrm{~m}$

\section{Peruaçu River}
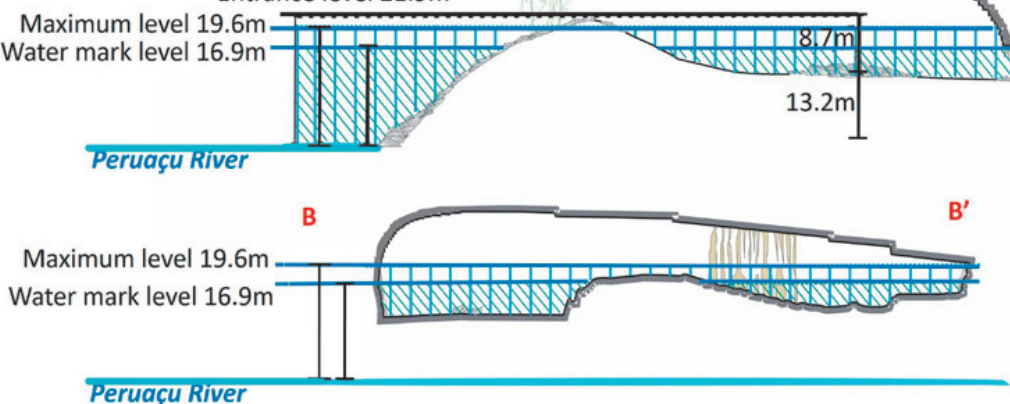

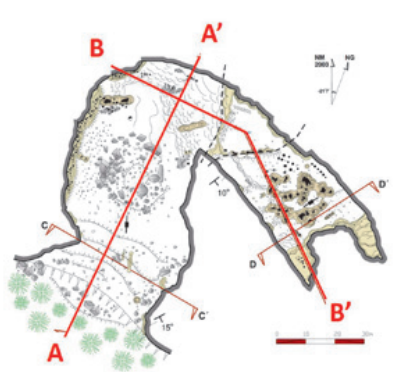

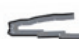

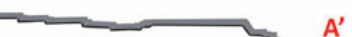

WANA ANWWWWMD

$13.2 \mathrm{~m}$

Fig. 9: Levels of deposition of collected and dated fossil samples, the highest sample found, and the water mark in the profiles of two segments in Carlúcio Cave and in relation to the Peruaçu river level. Source: Oliveira (2008). 
Tab. 6: Ages of flood events causing import of samples.

\begin{tabular}{|l|c|c|c|}
\hline Sample ID & Age (yr BP) & Event & $\begin{array}{c}\text { Event Age } \\
\text { (yr BP) }\end{array}$ \\
\hline Tr-01* - wood & $340 \pm 20$ & 4 & 320 to 360 \\
\hline Tr-02* - wood & $800 \pm 20$ & 3 & 780 to 820 \\
\hline F-03 - wood & $1610 \pm 50$ & 2 & 1560 to 3310 \\
\hline F-02 - shell & From $3260 \pm 50$ to $1701.5 \pm 430.5$ & 1 & 8002.5 to 9690 \\
\hline F-06- shell & From $9650 \pm 40$ to $8051.5 \pm 49.0$ & 2 \\
\hline
\end{tabular}

*According to Coelho (2013)

\section{DISCUSSION}

Among various processes that commonly result in accumulation of epigeal terrestrial mollusk shells in caves (Chambers and Steadman, 1986) the transportation as prey is excluded by the absence of predation marks on the shells; the transportation along with the sediment influx is not supported due to the empty inner cavities of the shells and; the accumulation of snail shells due to their retreat in moist areas during dry seasons seems unreliable due to their abundance in the aphotic zone, the heterogeneity of the deposition sites and their association with vegetal fossils exclude such possibility as a main factor in transport.

Fossil importation was a consequence of the natural impoundment of Peruaçu River and the resulting upstream WL rise. Thus, organic material floated into the cave and was entrapped upon the subsequent WL decrease, followed by a fossilization process inside the cave. Materials were imported into the Carlúcio Cave by water transport as a result of the rising water level from the Peruaçu River valley. Fluctuation was the selection factor acting upon the imported material, which resulted in the prevalence of shells in the deposit.

The Carlúcio Cave entrance is the only major element of contact with the outside environment through which the materials could have been imported. The amount of fossils, the diversity of deposition sites, the occurrence of plant material, and the existing WL marks all point to material transport by water. This is also evidenced by the fossil location high above the cave floor and the existence of several sub-compartments (segregated by speleothems) with scattered fossils, notably in the second segment. Such widespread elevation and plan-view distribution would hardly be achieved by mechanisms other than water-related ones.

It is inferred that columns that compartmentalize the cave plan view morphology worked as traps that have captured materials carried on the surface of the water stream. However, the considerable amount of fossils found at column bases and cave walls may result from decantation of elements that have lost their dynamic equilibrium upon encountering obstacles.

The fossil in the highest position was found at 19.6 meters above the river level, which is deemed the minimum level reached by the paleo-reservoir, as shells are not necessarily carried on the water surface and there may have been subsequent reworking. A WL recorded 5 meters below the cave entrance suggests the existence of an endogenous lake confined inside the Carlúcio Cave.

The virtual lack of large- and medium-sized animal bones, the absence of an association between fossil and sedimentary deposits, and the fossil taphonomy indicate low-energy, short-distance transport point to a gradual rise of the Peruaçu River water level. The lack of a planar shell apex orientation pattern and preferred vertical shell concavity orientation indicate the influence of low-velocity water currents when the cave was emptied and suggests also a gradual lowering of the Peruaçu River level.

The tree log sample age shows a minor error. Taking into account that wood is more prone to degradation in an external environment, it is believed that the age of F-03 tree $\log$ is close to the age of its importation event: $1610 \pm$ 50 years BP. The dated tree log sample was not associated with sediments or embedded in calcite. It showed signs of dehydration, and the age determined for this material allows extrapolating that tree logs are preserved for a considerable time in endogenous environments.

Shells, in turn, are a hard, weather-resistant material that can be preserved in external environments for many years after death. This limits the extrapolation of ${ }^{14} \mathrm{C}$ ages of shell fossils to approximate ages of material import events. In this sense, the ${ }^{230} \mathrm{Th} /{ }^{234} \mathrm{U}$ ages of calcite covers indicate the minimal age for the event.

Sample F-06 was imported into the Carlúcio Cave during the lower Holocene, between $9650 \pm 40$ and $8051.5 \pm 49.0$ years BP, the earliest flood record then dated in the Peruaçu River valley. Sample F-02 was im- 
ported by a flood dated $3260 \pm 50$ to $1701.5 \pm 430.5$ years BP. This sample's ${ }^{230} \mathrm{Th} /{ }^{234} \mathrm{U}$ age was considerably contaminated. The interval between the maximum and minimum age of the flood during which the shell F-02 was imported includes the age established for the tree log F-03 importation. Therefore, it is not possible to unquestionably state that shell F-02 was imported during a flood event separate from the flood event during which the log sample F-03 was imported.

Moreover, Coelho (2013) established the ages of 340 \pm 20 years $\mathrm{BP}(\mathrm{Tr}-01)$ and $800 \pm 20$ years $\mathrm{BP}(\mathrm{Tr}-02)$ for tree logs found in the Carlúcio Cave's photic zone. These ages are much lower than those determined in this study, which points to recurrent great floods. Considering the Coelho's data (2013) and the above mentioned results, there were at least four major floods in the Peruaçu River that resulted in flooding of the Carlúcio Cave. The oldest of such events was dated at least $8051.5 \pm 49.0$ years BP (F-06) and the most recent one at least $340 \pm 20$ years BP (Tr-01) (Tab. 6).

The occurrence of maize in the Peruaçu valley was previously studied in archaeological sites in caves by Freitas $(2001 ; 2004)$. Derived by indirect methods, their ages ranged from $620+/-60$ to $990+/-60$ years BP and from $570+/-60$ to $1,010+/-80$ years BP. The corncob found in the Carlúcio Cave was not dated, in order to preserve the deposit for future research. Prous (1986) believes that corn has been grown in Minas Gerais since at least 4,500 years BP and the oldest specimens in northern and northeastern Minas Gerais were found by Bird et al. (1991) in a 4,000 to 1,000 years BP chronological horizon.

Shells of the mollusk Drymaeus sp. (Bulimuloidea: Bulimulidae) represented $70 \%$ of the deposited shells and, except for a few samples, all Drymaeus sp. shells were virtually of the same size. It was not possible to establish the cause behind this fact, but it is inferred that selective transport may indicate a possible archaeological source for these materials. Schmitz et al. (1989) point out that gastropod mollusks, especially of the Bulimulidae family, were extremely important as a food source for the human population from 8,500 years BP to approximately 6,500 years BP. Palm fruit (Syagrus oleracea) and charcoal were also found in archaeological sites in the Peruaçu Valley caves of Boquete, Hora, and Caboclo (Freitas 2001; 2004; Prous 2007).

The Carlúcio Cave fossil deposit does not show a relationship between the deposition age and the respective elevation, or even between the chronology of events and the flood extent. Such findings stem primarily from the fact that the material was not necessarily at its original deposition site. Therefore, it is possible that the materials were rearranged when the cave was emptied, with the resulting decrease in elevation, and also during recent flood events, in which case the elevation could both rise and fall. Strong evidence of these deposit features is the location of tree log F-03 and Megalobulimus sp. shell F-06 samples at similar heights, approximately 19 meters above the Peruaçu River level, although these samples' ages are more than 7,500 years apart.

According to a study carried out by Coelho (2013), the breakdown block deposit found in the Onça Cave (Fig. 1) is the first siphoning point at the Peruaçu River capable of obstructing the river surface flow at very high elevations. There is a $46-\mathrm{m}$ altimetric difference between the local base level of the Peruaçu River upstream of this breakdown block deposit and the lowest elevation at the top of these blocks, where the river surface flow could be reestablished. This deposit comprises a variety of sediment sizes, with a large amount of clayish material between the coarsest clasts, which results in a low porosity deposit. In this reach, the Peruaçu River runs underground for 640 meters of breakdown blocks. Such breakdown block deposit structure creates a physical barrier in the Onça Cave that prevents the Peruaçu River from flowing on the surface, with the local base level rising by up to 46 meters, which is up to 6 meters above the Carlúcio Cave entrance (Coelho 2013). As the entrance is the Carlúcio Cave's highest elevation, floods that reached the height of 46 meters in the Onça Cave would have reached heights between 9 and 12 meters above the floor in the Carlúcio Cave, which means that this cave would have been virtually submerged.

Taking the maximum and minimum dates found for flood events during the Holocene, it is inferred that floods occur periodically since the breakdown block deposit was formed, with a minimum age of $8051.5 \pm 49.0$ yr. BP, according to the oldest event dated.

When evaluating paleoclimatic events based on stalagmites of a cave also located in the northern region of Minas Gerais, Stríkis et al. (2011) present a broad record for the period between 1,300 and 10,200 years BP. The study reports a large increase in rainfall in the years 9.2, 8.2, 7.4, 7.0, 6.6, 5.2, 4.0, 3.2, 2.7, 2.3, 2.2, and $1.9 \mathrm{kyr} \mathrm{BP}$, with duration of 50 to 300 years. Characterized as sudden precipitation fluctuation events, some of these records overlap the ages established for the transport of Megalobulimus sp. shell samples F-06 (events at 9.2 and $8.2 \mathrm{kyr}$ B.P.) and F-02 (events at 3.2 and $1.9 \mathrm{kyr}$ B.P.).

In a paleoclimatic study of the past 3,000 years in the Anjos Cave, located near the Peruaçu Valley, Stríkis (2015) found abrupt variations in stalagmite growth over short periods of time (around 10 years). The fastest growth rates took place between 1,650 and 1,870 CE (300 and 80 years B.P.), a period close to the age determined for sample Tr-01 (events between 340 and 320 years B.P.). 


\section{CONCLUSION}

The mechanism of sediment transport into caves through horizontal water flow is well-known. Yet, the fossil assemblage identified in the Carlúcio Cave provides evidence of a material transport and accumulation mechanism based on the rise in water level as a result of river floods.

The Carlúcio Cave location and morphology, and the deposit's taphonomic signature indicate upward transport of material in connection with the rise of the Peruaçu River WL as a result of barriers to the river's natural flow and consequent deposit entrapment upon WL lowering. The deposit of breakdown blocks in the Onça Cave that siphons the Peruaçu River stands out as a barrier structure given its capability of raising the WL to such an extent that the Carlúcio Cave would be flooded.

The fossil assemblage identified in the Carlúcio Cave comprises mainly terrestrial epigeal mollusk shells (1,399 individuals), $70 \%$ of which are Drymaeus sp. (Bulimuloidea, Bulimulidae). These fossils are not associated with sedimentary deposits and are abundantly distributed across different cave elevations and plan. They are mainly associated with areas with an abundance of speleothems, and most of the samples show some degree of calcite incrustation.

Analyzing sedimentary cave deposits is undeniably a complex task, as no stratigraphic relationship is neces- sarily found between the different levels of sediment deposition. Similarly, the Carlúcio Cave fossil deposit does not show any relation between deposit age and elevation. This feature poses an additional challenge in interpreting organic deposits in this cave.

The fossil deposit chronology indicates recurrent floods over time. At least four flood events that reached the Carlúcio Cave were identified based on dating of fossils from the Holocene period found in the cave. It is inferred that the WL elevation in the Peruaçu River canyon is associated with both water flow bottlenecking and episodes of increased water availability.

Some correlations with the region's pre-determined paleoclimatic records were developed on the basis of data from the Carlúcio Cave fossil assemblage and used as a potential source of chronological proxy records in the paleoenvironmental reconstruction of the Peruaçu valley in the Holocene period.

The selectivity in the transport of Drymaeus sp. mollusk shells and the occurrence of corncob and charcoal in the Carlúcio Cave fossil assemblage indicate that at least part of the material identified in the cave could have an archaeological origin. This hypothesis corroborates the intensive archaeological occupation of the Peruaçu River valley.

\section{ACKNOWLEDGEMENT}

Financial support was provided by CNPq. We acknowledge the contribution of the Postgraduate Program of Applied Ecology of the University of Lavras, GBPE, PARNA Cavernas do Peruaçu, IBAMA, ICMBio, and SBE. We are thankful to our research colleagues Joel Rodet, Ataliba Coelho, Luís Beethoven Piló, Rosângela Borém, Andréa
Mesquita, Paulo Simões and Ezio Rubbioli. We acknowledge the contribution of Dr. Xianfeng Wang and the University of Minnesota isotope laboratory in performing ${ }^{230} \mathrm{Th}$ dating. We are also immensely grateful to our Peruaçu colleagues Geovane da Hora, Flávio Gomes, Evandro da Silva, Seu Norinho, Dona Nita, Lú and Nildinha.

\section{REFERENCES}

Aguirre, M. L. \& E. A. Farinati, 1999: Taphonomic processes affecting late Quaternary molluscs along the coastal area of Buenos Aires Province (Argentina, Southwestern Atlantic).- Palaeogeography, Palaeoclimatology, Palaeoecology, 149, 283-304. DOI: http://dx.doi.org/10.1016/S00310182(98)00207-7
Alexandrowicz, S. W., 2000: Malacofauna of Holocene cave sediments of the Cracow Upland (Poland).Folia Quaternaria, 71, 85-112.

Alexandrowicz, W. P., 2000: Molluscan assemblages from cave and slope sediments of the Czêstochowa Upland (Poland).- Folia Quaternaria, 71, 113-137. 
Alexandrowicz, W. P. \& D. Rudzka, 2006: Molluscan communities from cave and slope deposits of the limestone rocky hills in the eastern part of podhale basin (Southern Poland).- Folia Malacologica, 14, 4, 191201. DOI: http://dx.doi.org/10.12657/folmal.014.017

Alexandrowicz W. P. \& E. Stworzewicz, 2003: Snails (Gastropoda).- In: Valde-Nowak P., Nadachowski A. \& T. Madeyska (eds.) Oblazowa Cave human activity, stratigraphy, and palaeoenvironment. Institute of Archeology and Ethnology, pp. 91-94, Kraków.

Anjos, A., 1918: O rio S. Francisco: o Vale do Rio S. Francisco será o celeiro do Brazil.- F. Borgonovo, pp. 62, Rio de Janeiro.

Auler, A. S., Piló, L. B., Smart, P. L., Wang, X., Hoffmann, D., Richards, D. A., Edwards, R. L., Neves, W. A. \& H. Cheng, 2006: U-series dating and taphonomy of Quaternary vertebrates from Brazilian Caves.- Palaeogeography, Palaeoclimatology, Palaeoecology, 204, 508-522. DOI: http://dx.doi.org/10.1016/j.palaeo.2006.03.002

Auler, A.S., Smart, P.L., Wang, X., Piló, L.B., Edwards, R.L. \& H. Cheng, 2009: Cyclic sedimentation in Brazilian caves: mechanisms and palaeoenvironmental significance.- Geomorphology, 106, 142153. DOI: http://dx.doi.org/10.1016/j.geomorph.2008.09.020

Baptista, M. C. \& L. Morato, 2003: Horizontes de mortandade de Megalobulimus sp. (Gastropoda) em cavernas.- Paleontologia em Destaque, 44, 56-56.

Bird, R. MCR., Dias JR., O. \& E. T. Carvalho, 1991: Subsídios para a arqueobotânica no Brasil: o milho mais antigo em cavernas de Minas Gerais, Brasil.- Revista de Arqueologia, 6, 14-31.

Cartelle, C. G., 1994: Tempo passado: mamíferos do Pleistoceno em Minas Gerais.- Palco, pp. 132, Belo Horizonte.

Cartelle, C. G., Abuhid, V., Ferreira, M. A. C. \& R. L. Ferreira, 1998: Levantamento Paleontológico.- In: IBAMA, CPRM. APA Carste de Lagoa Santa - MG.Technical report. IBAMA/CPRM, 177-197, Belo Horizonte.

Chambers, S. M. \& D. W. Steadman, 1986: Holocene terrestrial gastropod faunas from Isla Santa Cruz and Isla Floreana, Galápagos: evidence for late Holocene declines.- Transactions of the San Diego Society of Natural History, 21, 89-110. DOI: http://dx.doi. org/10.5962/bhl.part.24577

Cheng, H., Edwards, R.L., Hoff, J., Gallup, C.D., Richards, D.A. \& Y. Asmeron, 2000: The half-lives of uranium-234 and thorium-230.- Chemical Geology, 169, 17-33. DOI: http://dx.doi.org/10.1016/ S0009-2541(99)00157-6
Clifton, H. E., 1971: Orientation of empty pelecypod shells and shell fragments in quiet water.- Journal of Sedimentary Research, 41, 3, 671-682. DOI: http://dx.doi.org/10.1306/74D7231F-2B21-11D78648000102C1865D

Coelho, A. H. F., 2013: Registros de grandes alagamentos no cânion do rio Peruaçu, Parque Nacional Cavernas do Peruaçu - PNCP, MG.- MSc Dissertation. Universidade Federal de Minas Gerais, pp.136.

Cowling, R. M., Cartwright, C. R., Parkington, J. E., \& J. C. Allsopp, 1999: Fossil wood charcoal assemblages from Elands Bay Cave, South Africa: implications for Late Quaternary vegetation and climates in the winter-rainfall fynbos biome.- Journal of Biogeography, 26, 2, 367-378. DOI: http://dx.doi. org/10.1046/j.1365-2699.1999.00275.x

Ferreira, R. L., 2003: Depósitos em cavernas: registros de vida passada.- Bios, 11, 11, 39-52.

Ferreira, R. L., Souza, M., Santana, R., \& M. S. Silva, 2003: Bioespeleologia e paleontologia.- In: IBAMA, Fiat Automóveis S/A, CSD-Geoklock Geologia \& Engenharia Ambiental LTDA. Plano de manejo do parque Nacional Cavernas do Peruaçu - MG: relatórios de pesquisa das campanhas de avaliação ecológica rápida (AER).Technical report. IBAMA, 875-1026, São Paulo.

Freitas, F. O., 2001: Estudo genético-evolutivo de amostras modernas e arqueológicas de milho (Zea mays mays, L.) e feijão (Phaseolus vulgaris, L.).- PhD Thesis. Escola Superior de Agricultura Luiz de Queiroz, pp. 125.

Freitas, F. O., 2004: Uso de material arqueológico no estudo de evolução de plantas: estudo de caso: milho - Zea mays L. e mandioca - Manihot esculenta CRANTZ.- Revista de Arqueologia, 17, 33-40.

GBPE (Grupo Bambuí de Pesquisas Espeleológicas), 2003: Lapa do Carlúcio - MG 67.- In: IBAMA, Fiat Automóveis S/A, CSD-Geoklock Geologia \& Engenharia Ambiental LTDA. Plano de manejo do parque Nacional Cavernas do Peruaçu - MG: relatórios de pesquisa das campanhas de avaliação ecológica rápida (AER).Technical report. IBAMA, 3.334, São Paulo.

Hubbe, A. \& A. S. Auler, 2012: A large Cervidae Holocene accumulation in Eastern Brazil: an example of extreme taphonomical control in a cave environment.- International Journal of Speleology, 41, 2, 297-305. DOI: http://dx.doi.org/10.5038/1827806X.41.2.15

Hubbe, A., Haddad-Martim, P. M., Hubbe, M., Mayer, E. L., Strauss, A., Auler, A. S. \& W. A. Neves, 2011: Identification and importance of critical depositional gaps in pitfall cave environments: The fossiliferous deposit of Cuvieri Cave, eastern Brazil.- Palaeogeography, Palaeoclimatology, Palaeoecology, 312, 1, 66-78. DOI: http://dx.doi.org/10.1016/j.palaeo.2011.09.010 
Kidwell, S. M., 2001: Preservation of species abundance in marine death assemblages.- Science, 294, 5544, 1091-1094. DOI: http://dx.doi.org/10.1126/science. 1064539

Kidwell, S. M., Fursich, F. T. \& T. Aigner, 1986: Conceptual framework for the analysis of fossil assemblages.Palaios, 1, 28-238.

Ložek, V., 1980: Quaternary molluscs and stratigraphy of the Mažarna Cave.- Československy Kras, 30, 67-80.

Lund, P. W., 1845: Notice sur des ossements humains fossiles, trouvés dans une caverne du Brésil.- Mémoires de la Societé Royale des Antiquaires du Nord, 49-77.

Moldovan, O. T., Mihevc, A., Miko, L., Constantin, S., Meleg, I. N., Petculescu, A. \& P. Bosák, 2011: Invertebrate fossils from cave sediments: a new proxy for pre-Quaternary paleoenvironments.- Biogeosciences, 8, 7, 1825-1837. DOI: http://dx.doi.org/10.5194/ bg-8-1825-2011

Neves, W. A. \& L.B. Piló, 2003: Solving Lund's dilemma: new AMS dates confirm that humans and megafauna coexisted at Lagoa Santa.- Current Research in the Pleistocene, 20,57-60.

Oliveira, I. P. M. R., 2008: Barramentos naturais no vale do rio Peruaçu: consequências ecológicas e ambientais de eventos pretéritos e futuros. MSc Dissertation. Universidade Federal de Lavras, pp. 146.

Oliveira, I. P. M. R., Borém, R. A. T. \& R. L. Ferreira, 2009: Análise histórica dos estudos ambientais na região do vale cárstico do rio Peruaçu.- O Carste, 21, 3-21.

Paula Couto, C., 1953: Paleontologia brasileira: mamíferos.- Instituto Nacional do Livro Biblioteca Científica Brasileira, pp. 516, Rio de Janeiro.

Piló, L. B. \& E. Rubbioli, 2003: Cavernas do vale do rio Peruaçu: obra-prima de Carste Brasileiro.- In: Schobbenhaus, C. et al. (eds.). Sítios geológicos e paleontológicos do Brasil.DNPM/CPRM/SIGEP, pp. 453460, Brasília.

Polk, J. S., Van Beynen, P. E., \& P. P. Reeder, 2007: Late Holocene environmental reconstruction using cave sediments from Belize.- Quaternary Research, 68, 1, 53-63.

Prous, A., 1986: L`Archéologie au Brésil: 300 siécles d`occupation humaine.- L’Archéologie. 90, 257-308.

Prous, A., 2007: O Brasil antes dos Brasileiros: A pré-história do nosso país.- Zahar, pp. 142, Rio de Janeiro.

Reimer, P. J., Baillie, M. G., Bard, E., Bayliss, A., Beck, J. W., Bertrand, C. J. \& P. E. Damon, 2004: IntCal04 terrestrial radiocarbon age calibration, 0-26 cal kyr BP.- Radiocarbon, 46, 3, 1029-1058.

Rodet, J., Willems, L., \& A. Pouclet, 2015: The rio Peruaçu basin: An impressive multiphased karst system.- In: Vieira, B. C., Salgado, A. \& L. J. C. Santos (eds.) Landscapes and Landforms of Brazil. Springer, pp. 171-181, Dordrecht. DOI: http://dx.doi. org/10.1007/978-94-017-8023-0.
Rubbioli, E., 1999: Cavernas do Peruaçu: tópicos abordados no levantamento espeleológico da área de proteção ambiental.- O Carste, 11, 2, 34-37.

Rubbioli, E., David, H., Piló, L. B., Moura,V., Alt, L., Barrio, R., \& T. Vilaça, 2003: Espeleologia. In: IBAMA, Fiat Automóveis S/A, CSD-Geoklock Geologia \& Engenharia Ambiental LTDA. Plano de manejo do parque Nacional Cavernas do Peruaçu - MG: relatórios de pesquisa das campanhas de avaliação ecológica rápida (AER).- Technical report. IBAMA, 265286, São Paulo.

Schmitz, P. I., Sales Barbosa, A., Jacobus, A. L. \& M. Barberi Ribeiro, 1989: Arqueologia nos Cerrados do Brasil central: Serranopolis I.- Pesquisas- Antropologia, 44.1-208.

Simone, L. R. L., 2006: Land and freshwater molluscs of Brazil: an illustrated inventory on the Brazilian Malacofauna, including neighbor regions of the South America, respect to the terrestrial and freshwater Ecosystems.- Fapesp, pp. 390, São Paulo.

Souza, K., 1999: Paleontologia e sua Relação com a Espeleologia.- Espeleologia, 10, 44-45.

Stríkis, N. M., 2015: Atividade do Sistema de Monção Sul- americana na porção central do Brasil durante o último período glacial a partir da aplicação de isótopos de oxigênio em espeleotemas.- Doctoral dissertation. Universidade de São Paulo, pp. 265.

Stríkis, N. M., Cruz, F. W., Cheng, H.,Karmann, I., Edwards, R. L.,Vuille, M. \& A. S. Auler, 2011: Abrupt variations in South American monsoon rainfall during the Holocene based on a speleothem record from central-eastern Brazil.- Geology, 39, 11, 10751078. DOI: http://dx.doi.org/10.1130/G32098.1

Svoboda, J., Horáček, I., Ložek, V., Svobodová, H. \& J. Šilar, 2000: The Pekárna Cave. Magdalenian stratigraphy, environment and the termination of the loess formation in Moravian Karst.- Antropozoikum, 24, 61-79.

Szymanek, M., Krajcarz, M., Krajcarz, M. T. \& W. P. Alexandrowicz, 2016: Holocene palaeoecological changes recorded in mollusc-bearing cave sediments, Cave above the Słupska Gate (southern Poland).- Geologica Acta, 14, 3, 283-299.

Talma, A. S. \& J. C. Vogel, 1993: A simplified approach to calibrating (super 14) C dates.- Radiocarbon, 35, 2, 317-322.

Walker, S. E. \& S. T. Goldstein, 1999: Taphonomictiering: experimental field taphonomy of molluscs and foraminifera above and below the sediment-water interface.- Palaeogeography, Palaeoclimatology, Palaeoecology, 149, 1, 227-244. DOI: http://dx.doi. org/10.1016/S0031-0182(98)00203-X 
Wang, W., Potts, R., Baoyin, Y., Huang, W., Cheng, H., Edwards, R. L., \& P. Ditchfield, 2007. Sequence of mammalian fossils, including hominoid teeth, from the Bubing Basin caves, South China.- Journal of Human Evolution, 52, 4, 370-379.

White, W. B., 2007: Cave sediments and paleoclimate.Journal of Cave and Karst Studies, 69, 1, 76-93.

Yanes, Y.; Tomašových, A.; Kowalewski, M.; Castillo, C.; Aguirre, J.; Alonso, M. R. \& M. Ibanez, 2008: Taphonomy and compositional fidelity of Quaternary fossil assemblages of terrestrial gastropods from carbonate-rich environments of the Canary Islands.- Lethaia, 41, 3, 235-256. DOI: http://dx.doi. org/10.1111/j.1502-3931.2007.00047.x
Yesares-García, J. \& J. Aguirre, 2004: Quantitative taphonomic analysis and taphofacies in lower Pliocene temperate carbonate-siliciclastic mixed platform deposits (Almeria-Nijar basin, SE Spain).- Palaeogeography, Palaeoclimatology, Palaeoecology, 207, 1, 83-103. DOI: http://dx.doi.org/10.1016/j.palaeo.2004.02.002 